http://kitaibelia.unideb.hu/

ISSN 2064-4507 (Online) • ISSN 1219-9672 (Print)

(C) 2016, Department of Botany, University of Debrecen, Hungary

21 (2): 253-256.; 2016

DOI: $10.17542 /$ kit.21.253

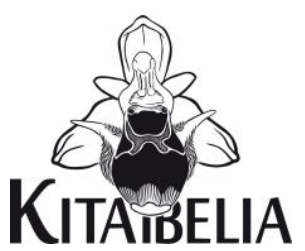

\title{
Aphanes arvensis L. a Crisicumban és más adatok Magyarország flórájának ismeretéhez
}

\author{
GulyÁs Gergely1, MaGos Gábor², MolnÁr Attila³ \& HoRVÁTH Dénes ${ }^{1}$
}

(1) Bioaqua Pro Kft., H-4032 Debrecen, Soó Rezső u. 21.

(2) Bükki Nemzeti Park Igazgatóság, H-3304 Eger, Sánc utca 6.

(3) H-4027 Debrecen, Domokos L. u. 8.

\begin{abstract}
Aphanes arvensis $\mathrm{L}$. in the Crisicum (E Hungary) and further data on the flora of Hungary
Abstract - New localities of 4 rare taxa are presented from Eastern Hungary. The species are new for the flora of particular floristical regions, specifically: „Eupannonicum”: Polystichum braunii; „Crisicum”: Aphanes arvensis; „Samicum” and „Nyírségense”: Agrimonia procera. Three new localities of the alien species Montia linearis in Hungary are presented. This species is still very rare in Europe, reported only from Poland, Denmark and Hungary.
\end{abstract}

Keywords: Crisicum, Eupannonicum, flora, Montia linearis, Nyírségense, Samicum

Összefoglalás - A közleményben 4 ritka növényfaj kelet-magyarországi előfordulásairól számolunk be. A fajok egyes flórajárásokra vagy flóravidékekre újnak számítanak: Alföld (Eupannonicum): Polystichum braunii; Tiszántúl (Crisicum): Aphanes arvensis; Észak-Alföld (Samicum) és Nyírség (Nyírségense): Agrimonia procera. A jövevény Montia linearis előfordulásához három új adatot közlünk Magyarországról. Ez a faj még mindig nagyon ritka Európában: csak Lengyelországból, Dániából és Magyarországról jelezték.

Keywords: Alföld, Észak-Alföld, flóra, Montia linearis, Nyírség, Tiszántúl

\section{Bevezetés}

Közleményünkben olyan fajok közelmúltban (2006-2016) felfedezett kelet-magyarországi előfordulási adatait mutatjuk be, amelyek jelenlétét az érintett flórajárásból vagy flóravidékről a rendelkezésünkre álló irodalom és herbáriumi anyag (BP és DE) tanúsága szerint korábban nem jelezték. A vizsgált terület növényföldrajzi felosztása tekintetében JÁvORKA \& Soó (1951) munkáját vettük alapul. A dűlőnevek az 1:10 000-es léptékű EOTR térképek névanyagát követik. Az előfordulási adatok mellett feltüntetjük a lelőhelyeket fedő flóratérképezési kvadrátok azonosítóit (NIKLFELD 1971).

\section{Enumeráció}

Aphanes arvensis L.: 2015. 04. 30-án és 2015. 05. 04-én Kismarja külterületén (a Crisicumban), az Óriás-part és a Középső-szik legelőin találtuk az Aphanes arvensis néhány száz töves állományát (KEF: 8796.2).

2016. 04. 07-én pedig Garbolc külterületén (a Samicum területén), a Hármashatár nevű 
legelő egy kisebb kiemelkedésén, ugyancsak legelőn találtuk meg (KEF: 8003.1).

A faj tiszántúli előfordulásáról, a magyarországi részről semmilyen korábbi irodalmi adatot nem találtunk (nem szerepel a Tiszántúl flórájában (Soó \& MÁTHÉ 1938), az azt kiegészítő munkákban (Soó 1940, 1948, Soó et al. 1942, UJVÁRosı 1940, 1941), továbbá nem találtunk tiszántúli lapot a Magyar Természettudományi Múzeum Növénytárának herbáriumában és a Debreceni Egyetem Soó Rezső Herbáriumában sem. Nem került be az Új magyar füvészkönyvbe (ANONYMus 2009) sem. A Magyarország edényes növényfajainak elterjedési atlasza - Atlas Florae Hungariae (BARTHA et al. 2015) a Dunától keletre egyetlen előfordulási adatot sem jelenít meg.

Legközelebbi gyűjtései: Nagyvárad (ma Románia: Oradea) (szántóföldeken a Szalka tanyánál, az ... erdőszél és Pece Szt Mártonnál), (Simonkai, 1876-77); Munkács (ma Ukrajna: Мукачеве) (inter segetes pr. Munkács), (Margittai, 1922); Árdánháza (ma Ukrajna: Арданово) (Com. Bereg. Ditio 'Háthegység'. Ad pagum Árdánháza.), (Thaisz, 1909). Utóbbi már nem az Alföldön található, hanem egy mintegy 150-200 m magas kis medencében a 400 m-t meghaladó gerincű Hát-hegység lábánál.

A Tiszántúllal ellentétben elmondható, hogy a Samicumból több előfordulási adat is származik. Először 1954-ben jelezte Simon Tibor (Simon 1954), aki a Beregi-síkon (Barabás) és a Szatmári-síkon (Nemesborzova) is megtalálta. Később Gondola (1969) közölte előfordulását a Beregi-síkról, Beregsurány és Márokpapi külterületéről, továbbá több átmeneti helyzetű területről, amelyeket ő a Samicumba helyezett, azonban ezek inkább a nyírségi Tisza-ártérhez tartoznak: Zsurk, Aranyosapáti, Nagyvarsány, Kisvarsány, Vásárosnamény, Vitka. 1969 óta azonban a fajnak közölt előfordulási adata, vagy gyújtése a Samicumból sincs.

Agrimonia procera Wallr.: Ezt a fajt 2006. 05. 11-én Garbolc külterületén, a 17. határkőtől D-re, a Lucska-csatorna menti fasorban és a cserjésedő gyepen (KEF: 8003.1), majd 2006. 05. 26-án Kishódos külterületén, a Pinkóci-tag és a Kovács-tag közötti fasorban, továbbá a Zsiga táblája és a Vaskapu-táj dűlők területén cserjésedő gyepeken találtuk meg (Szatmári-sík, Samicum) (KEF: 8002.2).

2015. 07. 17-én, 27-én és 28-án a Nyírségense területén Fábiánháza határában (a Disznókút-hegytől D-re (KEF: 8199.4), a Pince-hegyi-csatorna mellett (KEF: 8100.3) és a Nádasdűlőn (KEF: 8199.2)), majd 2016. 05. 10-én Monostorpályi határában (Bónis-hegy D-i szegélye, KEF: 8596.4) is megtaláltuk a faj 100 virágzó tövet meghaladó állományait. 2016. 08. 18-án Lovas-Kiss Ádám találta, ugyancsak Monostorpályi határában (belterület K-i széle, felhagyott szőlő és nemesnyáras között, KEF: 8696.2) 16 töves állományát. A nyírségi állományok főképp üde élőhelyekről: nem zsombékoló magassásosból, kiszáradó láprétről, akácosodó, gyomosodó láprétszegélyből (Fábiánháza), továbbá pusztulóban lévő lápi zsombékos szegélyéből (Monostorpályi) kerültek elő, egy monostorpályi állomány azonban nemesnyáras és felhagyott szőlő közötti szegélyterületen található.

A fajról részletes bemutatást és chorológiai értékelést közölt 2004-ben Király Gergely és Király Angéla (KIRÁLY \& KIRÁLY 2004), ennek alapján és saját herbáriumi kutatásaink szerint a fajnak a Samicumból és a Nyírségenséből korábbi előfordulási adata nem származott, egyedül Lenti István vette át és közölte hiányosan szatmári adatunkat egy a Túr élővilágáról szóló kiadványban (LENTI 2008). Az egész Eupannonicumból csupán a Kisalföldről volt ismert.

Polystichum braunii (Spenn.) Fée: Ennek a fajnak egyetlen példányát találtuk 2006. 05. 11én Nagyhódos külterületén, az Ásott-Túr jobb partja mentén húzódó erdőtömbben, keményfás ligeterdőben (Szatmári-sík, Samicum) (KEF: 8003.1). 2016-ban is megtaláltuk a példányt a lelőhelyen, egyértelműen jó állapotban. 2016-ban a Nyírségense területén is megtaláltuk a fajt, Újléta külterületén (Kis-erdő, KEF: 8597.3), akácos szegélybucka tövében, 
ahol keskeny elegyes ligeterdősáv húzódik, és egyébként nagyon gazdag páfrányokban (főleg a Dryopteris carthusiana állománya jelentős).

A fajnak korábban az Eupannonicum területéről nem közölték előfordulási adatát egyedül Lenti István vette át és közölte hiányosan szatmári adatunkat egy a Túr élővilágáról szóló kiadványban (LeNTI 2008) -, és nem találtunk alföldi lapot a Magyar Természettudományi Múzeum Növénytárának herbáriumában és a Debreceni Egyetem Soó Rezső Herbáriumában sem. A faj Magyarországon nagyon szórványos előfordulású - lásd pl. SiMON (2004), PinTÉr (2009), SEREGÉLYES (1999).

Legközelebbi gyűjtései a történelmi Szatmár és Bereg megyéből: Felsőbánya (ma Románia: Baia Sprie) (Thaisz, 1913), Nagybánya (ma Románia: Baia Mare) (Jávorka, 1913), Volóc (ma Ukrajna: Воловець) (Boros, 1933), Osza (nem település, vélhetően Oszatelep az Osza és Vicsa patakok torkolatánál. Ma Ukrajna: Oca) (Soó, 1940), Szarvasháza (ma Ukrajna: Жденієво) (Boros, 1938)

Montia linearis (Douglas) Greene: Ezt a fajt 2013. 05. 22-én Beregsurány külterületén, a Méhecske-dűlőtôl D-re, ecsetpázsitos rétben (KEF: 7801.3), 2013. 05. 23-án Márokpapi külterületén, a Bérelt-tag ecsetpázsitos rétjében (Beregi-sík, Samicum) (KEF: 7800.2), majd 2015. 04. 11-én Csaholc külterületén, a Jármi-erdőtől É-ra, az Erdő-dűlőn (Szatmári-sík, Samicum) (KEF: 8002.2) találtuk. Utóbbi területen a gyepet Elymus repens uralja, kevés a réti ecsetpázsit, jellemzőek posványsás- és veresnadrágcsenkesz-foltok. Igen mély belvizes csatornák árkolják. A rét enyhén zsombékol, a Montia a semlyékben él.

Ennek az adventív fajnak az elterjedéséről Magyarországon keveset tudunk. Jakab Gusztáv és Molnár V. Attila cikke (JAKAB \& MoLNÁr V. 2005) óta a szeghalmi előforduláson kívül nem közöltek újabb hazai adatot. Ahhoz a lelőhelyhez hasonlóan ezek az újabban előkerült állományok is a vasútvonalaktól és a forgalmas közutaktól távol találhatók. A faj továbbra is ritkának mondható Európában: Dembicz és munkatársai (DEMBICZ et al. 2015) szerint 2015-ben ismert európai állománya három lengyel, két dán és egy magyar előfordulásra korlátozódott.

\section{Köszönetnyilvánítás}

Hálásan köszönjük Somlyay Lajosnak és Takács Attilának, hogy az MTM Növénytár herbáriumában és a Soó Rezső Herbáriumban a tárgyalt fajok példányait számunkra átnézték. Köszönjük Szabó Tamásnak az irodalmazásban nyújtott segítségét, továbbá LovasKiss Ádámnak, hogy Agrimonia procera adatát közlésre átengedte!

\section{Irodalom}

Anonymus (2009): Aphanes L. - In: KirÁLY G. (szerk.), Új magyar füvészkönyv. Magyarország hajtásos növényei. Határozókulcsok. ANP Igazgatóság, Jósvafö, p. 220.

Bartha D., Király G., Schmidt D., Tiborcz. V., Barina Z., Csiky J., JakAB G., LesKu B., Schmotzer A., Vidéki R., Vојтко́ A. \& ZóLYомı Sz. (szerk.) (2015): Magyarország edényes növényfajainak elterjedési atlasza. Nyugat-magyarországi Egyetem Kiadó, Sopron, 329 pp.

Dembicz I., KozuB L. \& ZANiEwSKI P. T. (2015): Current state, habitat and potential invasiveness of Montia linearis (Douglas ex Hook.) Greene in Poland. - Acta Societatis Botanicorum Poloniae 84 (3): 347-356.

GonDoLA I. (1969): Florisztikai adatok a Nyírség és környéke szántóföldjeiről. - Botanikai Közlemények 56 (3): 167-173.

JAKAB G. \& MolnÁR V. A. (2005): A Montia linearis (Dougl.) Greene Magyarországon. - Kitaibelia 10 (1): 121-127.

JÁvoRKA S. \& Soó R. (1951): A magyar növényvilág kézikönyve I. - Akadémiai Kiadó, Budapest.

KIRÁLY G. \& KiRÁlY A. (2004): Az Agrimonia procera Wallr. előfordulása Magyarországon. - Flora Pannonica 2 (2): 7-23. 
LENTI I. (2008): A Túr-vidék élővilága. - In: LENTI I. (szerk.), Hová siet a Túr...? Szabolcs-Szatmár-Bereg Megyei Önkormányzat, Nyíregyháza, 199 pp.

NiKLFELD H. (1971): Bericht über die Kartierung der Flora Mitteleuropas. - Taxon 20 (4): 545-571.

PinTÉR I. (2009): Polystichum Roth. - In: KIRÁLY G. (szerk.), Új magyar füvészkönyv. Magyarország hajtásos növényei. Határozókulcsok. ANP Igazgatóság, Jósvafő p. 83.

Soó R. \& MÁTHÉ I. (1938): A Tiszántúl flórája. Flora Planitiei Hungariae Transtibiscensis. - Editio Instituci Botanici Universitatis Debreceniensis, 192 pp.

Simon T. (1954): Montán elemek az Észak-Alföld flórájában és növénytakarójában III. - Annales Biologicae Universitatum Hungariae 2: 279-286.

Simon T. (2004): A magyarországi edényes flóra határozója. - Nemzeti Tankönyvkiadó, Budapest, 845 pp.

Soó R., FELFöLDY L. \& IGMÁNDY J. (1942): Pótlékok nyírségi és tiszántúli flórakutatásunk eredményeihez III. - Botanikai Közlemények 39: 45-56

Soó R. (1948): Tiszántúli flórakutatásaink újabb eredményei. Pótlások Soó-Máthé Tiszántúl flórájához V. - Borbásia 8 (1-8): 48-57.

Seregélyes T. (1999): Polystichum braunii. - In: FARKAS S. (szerk.), Magyarország védett növényei. Mezőgazda Kiadó, Budapest, p. 99.

UJvÁrosı M. (1940): Pótlások Soó-Máthé "Tiszántúl flórájá"-hoz. - Debreceni Szemle 14 (5): 104-107.

Soó R. (1940): Hajdúszoboszló virágos növényei. (Pótlások Soó-Máthé: Tiszántúl flórájához, II.) Debreceni Szemle 14 (7): 161-164.

UjváRosı M. (1941): Adatok a borsodi sík flórájához Budai József gyűjtéséből. (Pótlások Soó-Máthé: Tiszántúl flórájához III.) - Debreceni Szemle 15 (1): 6-10.

Beérkezett / received: 2016. 09. 28. • Elfogadva / accepted: 2016.10. 28. 